\title{
A KÖTŐDÉSELMÉLET VÁLTOZÓ ARCA: KURRENS TRENDEK NAPJAINK KÖTÖDÉSKUTATÁSAIBAN
}

\author{
HÁMORI ESZTER \\ Pázmány Péter Katolikus Egyetem, BTK, Pszichológiai Intézet, \\ Fejlődés- és Klinikai Gyermeklélektan Tanszék \\ E-mail: hamori.eszter@btk.ppke.hu
}

Az elôszó a kötetben szereplő elméleti és empirikus kötődés tanulmányok gyüjteményének aktualitását emeli ki, és helyezi el napjaink modern kötôdéskutatásainak kurrens trendjei között.

Kulcsszavak: kötődéskutatás, kurrens trendek, elméleti és empirikus tanulmányok

Bowlby $(1969,1974,1980)$ kötôdéselmélete a csecsemô és a gondozója között kialakuló speciális érzelmi kötelék természetét új megvilágításba helyezte az etológiai kerettel. A korai interakciók sajátosságait leképezó belsố munkamodell fogalma és a csecsemôkori viselkedés Ainsworth (1978) által megfigyelt egyéni különbségei - a biztonságos, a szorongó-elkerüló és a szorongó-ambivalens kötôdési mintázat - a két legtermékenyebb koncepció lett az elmúlt évtizedek kötôdéskutatatásaiban, valamint a fejlôdéslélektan és a személyiségpszichológia érzelmi, kapcsolati és én-szervezôdéssel foglalkozó vizsgálataiban. Az elmélet születése óta eltelt 60 év jelentôs eredményeket, változásokat hozott: fejlődtek a gyermek-, a serdülô- és a felnôttkori kötődés mérésére szolgáló eljárások, ami lehetôvé tette, hogy az elmélet eredeti feltevéseit és eredményeit igazolni, cáfolni vagy éppenséggel továbbgondolni lehessen. Az életútkutatások és a pszichopatológiai jelenségek kötôdésvizsgálatai új paradigmák születéséhez is hozzájárultak, így például a modern fejlôdési pszichopatológia új modelljeinek felállításához (Achenbach és Rescorla, 2016). A kötôdés csecsemôkori fejlôdésének interakciós vizsgálatai, a genetikai, epigenetikai folyamatok kutatása, a kulturális különbségeket befolyásoló tényezôk feltérképezése és a fejlôdési átmenetek dinamikai jellemzóinek megismerése mind olyan témákat képviselnek, amelyek fémjelzik a kötôdéselmélet módszereinek és koncepcióinak robbanásszerú fejôdését az utóbbi 15-20 évben (Cassidy és Shaver, 
2016). Ezek a változások egyfelôl inspiratívak, ugyanakkor jelentôs kihívás elé állítják a kutatókat a növekvố konceptuális sokféleség miatt. Napjainkban több területen is paradigmaváltás zajlik az elméleten belül. A klasszikus kategorizációs modellt egyre inkább felváltja a kötôdés dimenzionális szemlélete, valamint a tranzakcionális modell keretében értelmezett kölcsönhatások vizsgálata.

Rendkívül nagy a változatosság és igen sok a meg nem oldott elméleti és módszertani probléma a kötôdéskutatásokban. Módszertani szempontból különösen kritikus terület a gyermek-, a serdülố- és a felnôttkori kötôdés fejlôdési változásainak és az ezeket meghatározó tényezóknek a kutatása. Egyre több, számos vizsgálatot összegzó metaanalízis áll rendelkezésünkre, ami lehetôvé teszi komplexebb magyarázó modellek felállítását a kötôdés normatív folyamatairól, fejlôdési változásairól, valamint az egészséges és patológiás mûködésmódok biológiai, viselkedéses, kulturális és társas meghatározóiról (Bakermans-Kranenburg és van IJzendoorn, 2016).

A tematikus szám különlegessége, hogy magyar akadémiai és egyetemi kutatómúhelyekben, a modern paradigmák és modellek szellemében született elméleti és empirikus tanulmányokat olvashatunk. A kötetben 3 fố témakör köré szerveztük ezeket a munkákat: A kötôdés biológiai, kulturális és társas vonatkozásait 3 tanulmány tárgyalja: Gervai Judit és munkatársai a korai kötôdés fejlôdésében szerepet játszó genetikai és epigenetikai hatásokra vonatkozó hazai és nemzetközi eredményeket foglalják össze. A kötôdés kulturális különbségeinek klasszikus és új adatait, valamint a különbségek modern magyarázó elképzeléseit elemzi Fülöp Márta és Szabó Zsófia. Berán Eszter és munkacsoportja a társas háló és a kötôdés összefüggéseire vonatkozó empirikus kutatásuk eredményeit mutatja be. A másik fô témakörbe olyan tanulmányokat gyưjtöttünk, amelyek a kötôdés fejlōdési változásairól és az azokban szerepet játszó folyamatokról szólnak. Tóth Ildikó és munkatársai a csecsemókori atipikus anyai viselkedés, a közös figyelem és a kötôdés összefüggéseire vonatkozó új eredményeiket mutatják be. Pohárnok Melinda és munkacsoportja a kisgyermekkori szelf-fejlôdés és a szülő-gyermek dialógusok kötôdésben játszott szerepére vonatkozó kutatásokat foglalják össze. Hámori Eszter és Horváth Julia empirikus tanulmánya a kötôdés élményrétegeinek serdülő- és felnôtttkori sajátosságait vizsgálja. Végül a harmadik téma klinikai vonatkozású: a kötôdés és betegségélmény összefüggéseiról Désfalvi Judit és munkatársai emlôrákkal küzdô nôkkel folytatott vizsgálata szól.

Összefoglalva, a kötôdéskutatások kiemelt területeit középpontba helyezô tanulmányokat olvashatunk jelen lapszámban: új elméleti és empirikus fejleményekrôl, módszerekrôl, modellekrôl és vizsgálati paradigmákról, amelyek jelzik, hogy a modern kötôdéskutatások Magyarországon is dinamikusan fejlődnek napjainkban.

Budapest, 2017. január

Hámori Eszter 


\title{
IRODALOM
}

Achenbach, T. M., \& Rescorla, L. A. (2016). Developmental issues in assessment, taxonomy and diagnosis of psychopathology lifespan and mulitcultural perspectives. In D. Cicchetti (Ed.), Developemtnal Psyhopatology, Third Edition. Volume One: Theory and Method (pp. 46-94). Hoboken, NJ: Wiley.

Ainsworth, M. D. S., Blehar, M., Waters, E., \& Wall, S. (1978). Patterns of attachment: A psychological study of the strange situation. Hillsdale: Erlbaum.

Bakermans-Kranenburg, M. J., \& van IJzendoorn, M. H. (2016). Attachment, parenting and genetics. In J. Cassidy, \& P. R. Shaver (Eds.), Handbook of attachment. Theory, research, and clinical applications. 3. ed. (pp. 155-180). New York: The Guilford Press.

Bowlby, J. (1969). Attachment and Loss: Volume 1: Attachment. The International Psycho-Analytical Library, 79, (pp. 1-401). London: The Hogarth Press and the Institute of Psycho-Analysis.

Bowlby, J. (1974). Attachment and Loss: Volume II: Separation, Anxiety and Anger. The International Psycho-Analytical Library, 95, (pp. 1-429). London: The Hogarth Press and the Institute of Psycho-Analysis.

Bowlby, J. (1980). Attachment and Loss: Volume III: Loss, Sadness and Depression. The International Psycho-Analytical Library, 109, (pp. 1-462). London: The Hogarth Press and the Institute of Psycho-Analysis.

Cassidy, J., \& Shaver, P. R. (Eds.) (2016). Handbook of attachment. Theory, research, and clinical applications. 3. ed. New York: The Guilford Press.

\section{THE CHANGING FACE OF ATTACHMENT THEORY: CURRENT TRENDS IN RECENT ATTACHMENT RESEARCH}

\author{
HÁMORI, ESZTER
}

The preface highlights the actuality of the collection of the theoretical and empirical attachment studies of this volume and places them among the current trends in todays' modern attachment researches.

Keywords: attachment research, current trends, theoretical and empirical studies 